\title{
ASSESSING WEB SITE USABILITY MEASUREMENT
}

\author{
Nur Sukinah Aziz ${ }^{1}$, Adzhar Kamaludin ${ }^{2}$, Norrozila Sulaiman ${ }^{3}$ \\ ${ }^{I}$ Faculty of Computer, Media and Technology Management, TATI University College, Kemaman, Terengganu, Malaysia \\ ${ }^{2,3}$ Faculty of Computer Systems \& Software Engineering, Universiti Malaysia Pahang, Kuantan, Pahang, Malaysia \\ nursukinah@tatiuc.edu.my,adzhar@ump.edu.my,norrozila@ump.edu.my
}

\begin{abstract}
Web evaluation has been used in decade to validate the web site to see how it performs. When analysing a web site, typical factors to be considered are the way the information is organized and presented, and how to access and navigate the informative structure [1]. Usability evaluations evaluate the ease of use of a web site functions and see either the user can perform their tasks efficiently. This paper review existing usability standards and models in determining an appropriate model for evaluating the usability of web site. Previous research are reviewed and comparison and analysis of existing usability model and identification of usability criteria and characteristics for web site is made to identify the attribute or characteristic that should be used in evaluating web site.This study proposed an extension of the QUIM model as a basic model for usability model for a web site. Therefore, a set of guidelines to assist in determining design and usability
\end{abstract}

Keywords: web site usability, usability model, usability attributes, QUIM model. $* * *$

\section{INTRODUCTION}

Evaluation research is necessary to monitor and further improve the quality of the web sites and use expert focused and user focused methods to evaluate the web site [2]. A web site is one or more web page that relate to a common theme such as a person, business or organization. The front page is usually called home page and inside the home page it has the content on the web site. A home page also known as an index From the home page, there have hyperlinks to access other web pages within the web site. There are many methods can use to evaluate the web site. Usability is one of the major factors that determines the successfulness of a website [3][4]. Usability in the context of web application does not cover only user interface but includes the content or the information, and functionalities that application could perform [5]. Poor web design will make user away and give poor reputation to the organization [3][6]. Web design is creative process of building the visual arrangement of text, graphics and other elements contained in the web site. Beside that business oriented web site or e-commerce can make organization loss of revenue if the web site has usability problem [7][8]. Ease of use, the ability to access the correct information quickly and customer satisfaction are the important element for information retrieval according the research [9]. However, the list of usability as well as the related factors, criteria, and metrics is not consistently defined across different standards or models [10]. While studies were useful, they have also caused confusion because many usability aspects offered.

\section{LITERATURE REVIEW}

This section presents several usability models as the foundation for proposing an appropriate model for web site usability. The selected models are the standard and acceptable model includes Eason, Shackel, Nielson, ISO 9241 - 11, ISO 9126 and QUIM Model.

\subsection{Usability Definition}

Usability is one of the important characters to make product such as web site or software usable and quality. Web site evaluation is determining the quality of the web site. There are many factors or characteristics to determine the quality of web site or software [5] [11]. Usability is the most factor in web site or software quality. There are many quality model that has usability as quality criteria such as McCall's Quality Model, Boehm's Quality Model, ISO 9126 Quality Model, FURPS Quality Model, Dromey's Quality Model and QUIM Quality Model [11]. Many researchers adapted software usability in web site usability[12][5][13][14]. Nowadays, web site is use widely all over a world for medium of communication for information or services and usability principles was implementing in web environment and not for software only. Organization using web sites to market their product and services User will always used the web site if the web site can achieve their task or goal for searching the information or using it services more quickly, easily and effectively [15] [16].

There are many definitions or term about usability. Human Computer Interaction (HCI) is about designing computer systems that support people so that they can carry out activities productively and safely. In HCI term, usability is 
more to usable user interface or in other word to make system easy to learn and easy to use [17]. Based on ISO $9241-11$ in HCI field, usability is defined as the "the extent to which a product can be used by specified users to achieve specified goals with effectiveness, efficiency and satisfaction in a specified context of use" [18][5]. Refer to the definition, the criteria of usability are effectiveness, efficiency and satisfaction. It focuses on human interaction perspective for software product standard. This definition has 3 components that can divide such as "specified users", "achieve specified goals" and "specified context to use". This definition is more clearly what usability is mean and many researchers use this definition [17]. In the field of Software Engineering (SE) in ISO 9126-1, usability is defined as " the capability of the software product to be understood, learned, operated, attractive to the user, and compliant to conditions" [5]. It has 6 characteristics such as functionality, reliabity, usability, efficiency, maintainability and portability [19] [20] [21]. Each of the attributes has their own sub - characteristics. For sub attributes in usability under ISO 9126-1 are understandability, learnability, operability, attractiveness and usability compliance. Some researchers has combine ISO 9126 and ISO 9241 attributes and develop new model that has effectiveness, efficiency, satisfaction, learnability and security as attributes [22]. Usability standards provided by (ISO) the International Standards Organization can be broadly classified into two categories first, product-oriented standards (ISO 9126, 2001; ISO 14598, 2001) and second, process-oriented standards (ISO 9241, 1992/2001; ISO 13407, 1999).

Based on Benbunan-Fich, the usability is defined as " how well and how easily a user, without formal training can interact with an information system of a web site" [23]. According research [24], the element in usability are learnability and efficiency, aesthetics and navigation, content and functionality, accuracy and consistency, technical adequacy, help and documentation and error removal. Judy Jeng (2005) also use effectiveness, efficiency, satisfaction and learnability as attributes for usability model for digital library. She also group usability to two group that is inherent usability and apparent usability. Inherent usability means to make product easy to understand, easy to learn, efficient to use, less erroneous and pleasure. Apparent usability is more related to visual impression of the interface [25]. Information layout, server response time, time to load, download time and speed are the most important variables for web page design [9]. In the context of web site usability that has specified users, specified goals and specified context of use. That mean user has it own role and has it own objective and task to use the web site in environment and domain in actual usage. Web site usability can define as a quality attribute that assesses how easy user interfaces are to use. The definition can divide in two ways that look to interface or final product based on its attributes and other hand refer to methods for improving ease of use during the design process or the approach used to conduct usability research [26] [27].
Based on study by [20], they analysis the element or attribute for usability by explore published definitions of usability. They found that learnability, satisfaction, flexibility, efficiency, effectiveness and memorability are the most frequency in 37 formal definitions. 2.2 Review of Usability model

\subsection{Review of Usability Model}

According to [28], usability is a product attributes that give impact or influences the quality of a software system. Usability models are conceptual view and not only states the characteristics but also indicates how those characteristics fit together. There are several usability model such as Eason Model (1984), Shackel Model (1991), Nielsen Model (1993), ISO 9241-11(1998), ISO 9126 (2001) and QUIM model (2006).

\subsubsection{Eason Model (1984)}

Eason Model is proposed by Kenneth Eason (1984) and published his model in an early issue of Behaviour and Information Technology. Eason Model has 3 aspect, task, user and system. For task it has 2 sub attribute that is frequency and openness. User has 3 sub attributes that is knowledge, motivation and discretion. System has ease of learning, ease of use and task match. Eason Model cannot measure usability without considering users and their target task. Based on Eason's model, it has two parts that is input and outcome. The input for Eason's model is user, system, task characteristic and can define as independent variables. The outcome is user reaction and it dependent variable. Eason model is causal type of model because it has input that is independent variable and outcome or result that is dependent variable. A causal model is one that makes prediction about causality. Eason model sees usability as the result of several interacting variables or "multi - variate". [17][28].

\subsubsection{Shackel Model (1986)}

Shackel Model was developed by Brian Shackel. In this model, it has 4 attributes that is effectiveness, learnability, flexibility and attitude. Shackel Model does not weight the dimension, recognizing that the importance of each of these may different from project to project. Shackel model emphasizes measurement of a number of human factors, relating to human performance and attitude [17] [28]. [29] Modified Shackel model and adapted the model into usefulness, effectiveness, learnability ( or ease of use ) and attitude (or likeability). Booth did not include flexibility because he thought difficult to specify and measure the flexibility of a system and include useful to be consider as fundamental to usability [20][28]. [30][31] said that definition with one or more of four criteria in Booth model are generally accepted by usability community. Likeability also important to usability which constitutes user's perception, feelings and opinion of product [20][28]. 


\subsubsection{Nielson Model (1993)}

Nielson Model was developed by Jakob Nielson. The main model is system acceptability and usability is part of usefulness as figure 2. Other attribute that contribute to the main model are utility, usefulness, practical acceptability and social acceptability. Under usability it has 5 attributes such as easy to learn (learnability), efficient to use (efficiency), easy to remember (memorability), few error and subjectively pleasing (satisfaction). Nielson Model focus on acceptability that mean if the system is not useful such as did not meet the user requirement, it will not accept it either it usable or not. The model is based on user interface usability in the context of a software engineering project. Nielsen emphasizes usability as part of a larger set of system characteristics. Same with Shackel Model, Nielson Model also does not weight the dimension, recognizing that the importance of each of these may different from project to project. Nielson model is additive model [17] [28]. Nielson categories the attribute as below [32]:

\subsubsection{ISO 9241 - 11 (1998)}

ISO 9241 is an international standard for guidance on usability based on process oriented. Nielson and Shneiderman are among the committee members in the development of ISO guidelines. For ISO 9241 - 11 has 3 attributes that are effectiveness, efficiency and satisfaction. ISO $9241-11$ are put together from a different usability viewpoint. Effectiveness describes the interaction from the process viewpoint, efficiency which focus on results and resources involved and satisfaction which is a user viewpoint [22][33][28]. ISO 9241-11 has objective measures of usability [34]. The disadvantage of this model is that it is to abstract [10] [35].

\subsubsection{ISO 9126 (2001)}

ISO 9126 is an international standard for the evolution of software quality model from the product perspective. The approach was quality model of the product and initially published in 1991 and refined over the next ten years by ISO's group of software engineering experts. ISO 9126 is an extension of previous work done by McCall (1977), Boehm (1978), FURPS and others in defining a set of software quality characteristics [36]. ISO 9126 divided into 4 parts which address respectively to the quality model, external metrics, internal metrics and quality in use metric. The internal and external metrics are functionalities, reliability, usability, effectiveness, maintainability and portability [22]. Under usability it has 5 attributes such as understandability, learnability, operability, attractiveness and usability compliance [22][33][28]. The advantage of ISO 9126 model is it provide a framework for making trade-offs between software product capabilities and the attribute are applicable to any kind of software including computer programs and provide consistent terminology for software product quality.
The disadvantage of ISO 9126 was unclear architecture at the detail level of the measures, overlapping concepts, lack of a quality requirement standard, lack of guidance in assessing the results of measurement and ambiguous choice of measures [34].

\subsubsection{Quality in Use Integrated Measurement (QUIM) (2006)}

QUIM or Quality in Use Integrated Measurement developed by Ahmed Seffah et al in 2006 QUIM is a consolidated model for usability measurement and metrics. It combines various standard and model such as ISO 9241 and ISO 9126 and unified into a single consolidated, hierarchical model. It outlines methods for establishing quality requirements as well as identifying, implementing, analyzing, and validating both process and product quality metrics. This model appropriate for novice users that have little knowledge of usability and can be applied by usability experts and non-experts QUIM model consists of 10 factors and subdivided into 26 criteria or measurable criteria, and finally into specific metrics consists 127 specific metrics. The 10 factors consists Efficiency, Effectiveness, Satisfaction, Learnability, Productivity, Safety, Trustfulness Accessibility, Usefulness and Universality. The model is used to measure the actual use of working software and identifying the problem. In QUIM model associates factors with criteria and metrics in a clear and consistent way. It also usable generally and can adapt in specific context of use. The limitation of this model, it is not optimal yet and needs to be validated [10] [35] [37].

\section{PROPOSED MODEL}

Some of the usability models have been discussed in this paper. Refer to table 1 for their main features in usability model and other researchers that have been made in previous study. There are many attributes in each model but there has similarity between the models. Table 2 presented the similarity between the models.

Table 1 : Similarity between the usability model

\begin{tabular}{|c|c|c|c|c|c|c|}
\hline & $\begin{array}{c}\text { Eas } \\
\text { on } \\
\text { Mo } \\
\text { del }\end{array}$ & $\begin{array}{c}\text { Sh } \\
\text { ac } \\
\text { ke } \\
\text { l } \\
\text { M } \\
\text { od } \\
\text { el }\end{array}$ & $\begin{array}{c}\text { Niel } \\
\text { son } \\
\text { Mod } \\
\text { el }\end{array}$ & $\begin{array}{c}\text { ISO } \\
9241 \\
-11\end{array}$ & $\begin{array}{c}\text { IS } \\
\text { O } \\
912 \\
6\end{array}$ & $\begin{array}{c}\text { QUI } \\
\text { M }\end{array}$ \\
\hline $\begin{array}{l}\text { Effectivenes } \\
\mathrm{s}\end{array}$ & & $\sqrt{ }$ & & $\sqrt{ }$ & & $\sqrt{ }$ \\
\hline Efficiency & $\sqrt{ }$ & & $\sqrt{ }$ & $\sqrt{ }$ & & $\sqrt{ }$ \\
\hline Learnability & $\sqrt{ }$ & $\sqrt{ }$ & $\sqrt{ }$ & & $\sqrt{ }$ & $\sqrt{ }$ \\
\hline Satisfaction & & & $\sqrt{ }$ & $\sqrt{ }$ & & $\sqrt{ }$ \\
\hline $\begin{array}{l}\text { Accessibilit } \\
\mathrm{y}\end{array}$ & & & & & & $\sqrt{ }$ \\
\hline
\end{tabular}


From table 1, 4 attributes are selected based on frequency in each model and other study made by researchers to see the similarity and represent it in table 2 . The attribute that have been selected are effectiveness, efficiency, learnability and satisfaction. As results in table 1 and 2 , the 4 usability attributes that have been use frequently in the previous model are selected since they are suitable and important to evaluate usability on web site. Learnability is the most attribute or characteristic that used among the models. The satisfaction attribute selectable because to determine whether the web site is usable or not. If the user feels more satisfied, they are willing to reuse and revisit he web portal based on the study Arbaugh and Duray (2002). In addition, more satisfying experiences sometimes lead to better learning performance in the future based on the study conducted by Shih, Muroz, \& Sanchez, 2006 [38]. Based on table 2, it can be concluded that among the usability model, QUIM model is more complete than other models and suitable to be used in the web site usability because it consolidated model based on previous works and model. QUIM model brings together usability factors, criteria, metrics and data mentioned in various standards or model for software quality and defines them and their relations with one another in a consistent way [10].

Based on the discussions above, QUIM model as a based in this study and modified it focusing on web site. In table 3, QUIM model used 4 attribute that are Effectiveness, Efficiency, Learnability, Satisfaction and also include Accessibility. This model also based on ISO standards and previous research in the area usability and quality in use. The context of use is considered when selecting the aspects of the web site that should be measured. In this way, the consideration of context in usability measurement will ideally make such measurement more realistic and meaningful.[10]

Below in table 3 are the attributes or characteristics that are choose as the element in the model. In table 4 relation between the criteria and characteristics for web site usability are presented. This refinement is done in order to ensure a systematic approach for evaluating the usability of web site thoroughly

\begin{tabular}{|c|c|}
\hline $\begin{array}{c}\text { Attributes / } \\
\text { characteristics }\end{array}$ & Description \\
\hline Effectiveness & $\begin{array}{l}\text { - refer to how good a web site is at doing } \\
\text { what it is supposed to do / the capability } \\
\text { of the web site to enable users to achieve } \\
\text { specified tasks with accuracy and } \\
\text { completeness }\end{array}$ \\
\hline Efficiency & $\begin{array}{l}\text { - the way a system supports user in } \\
\text { carrying out their tasks. / the capability of } \\
\text { the software product to enable users to } \\
\text { expend appropriate amounts of resources } \\
\text { in relation to the effectiveness achieved in } \\
\text { a specified context of use. }\end{array}$ \\
\hline Learnability & $\begin{array}{l}\text { - refer to how easy a web site is to learn to } \\
\text { use. }\end{array}$ \\
\hline Satisfaction & $\begin{array}{l}\text { - refer to how users comfort to use the } \\
\text { web site and their positive attitude after } \\
\text { use the web site. / refers to the subjective } \\
\text { responses from users about their feelings } \\
\text { when using the software / the ease with } \\
\text { which the features required for achieving } \\
\text { particular goals can be mastered. It is the } \\
\text { capability of the software product to } \\
\text { enable users to feel that they can } \\
\text { productively use the software product } \\
\text { right away and then quickly learn other } \\
\text { new (for them) functionalities. }\end{array}$ \\
\hline Accessibility & $\begin{array}{l}\text { - refer to how easy the user to access the } \\
\text { web site even to disability user. / the } \\
\text { capability of a software product to be used } \\
\text { by persons with some type of disability } \\
\text { (e.g., visual, hearing, psychomotor). The } \\
\text { World Wide Web Consortium (Caldwell } \\
\text { et al., 2004) suggested various design } \\
\text { guidelines for making Web sites more } \\
\text { accessible to persons with disability }\end{array}$ \\
\hline
\end{tabular}

Table 2 : Features comparison between the usability model

\begin{tabular}{|l|l|l|l|l|l|l|l|l|l|}
\hline $\begin{array}{l}\text { Eason } \\
\text { Model } \\
\mathbf{( 1 9 8 4 )}\end{array}$ & $\begin{array}{l}\text { Shack } \\
\text { el } \\
\text { Model } \\
\mathbf{( 1 9 8 6 )}\end{array}$ & $\begin{array}{l}\text { Shack } \\
\text { el } \\
\text { Model } \\
\mathbf{( 1 9 9 1 )}\end{array}$ & $\begin{array}{l}\text { Schneid } \\
\text { erman } \\
\mathbf{( 1 9 9 2 )}\end{array}$ & $\begin{array}{l}\text { Nielson } \\
\text { Model } \\
\mathbf{( 1 9 9 3 )}\end{array}$ & $\begin{array}{l}\text { Preece et } \\
\text { al. } \\
\mathbf{( 1 9 9 4 )}\end{array}$ & $\begin{array}{l}\text { ISO 9241 } \\
\mathbf{1 1}(\mathbf{1 9 9 8})\end{array}$ & $\begin{array}{l}\text { Constantin } \\
\text { e } \\
\text { Lockwood } \\
\mathbf{( 1 9 9 9 )}\end{array}$ & $\begin{array}{l}\text { ISO 9126 } \\
\mathbf{( 2 0 0 1 )}\end{array}$ & QUIM (2006) \\
\hline $\begin{array}{l}\text { Easy to } \\
\text { use }\end{array}$ & $\begin{array}{l}\text { Effecti } \\
\text { veness }\end{array}$ & $\begin{array}{l}\text { Effecti } \\
\text { veness } \\
\text { (speed } \\
\text { ) }\end{array}$ & $\begin{array}{l}\text { Speed } \\
\text { of } \\
\text { perform } \\
\text { ance }\end{array}$ & $\begin{array}{l}\text { Efficient } \\
\text { to use }\end{array}$ & $\begin{array}{l}\text { Through } \\
\text { put }\end{array}$ & Efficiency & $\begin{array}{l}\text { Efficiency } \\
\text { in use }\end{array}$ & $\begin{array}{l}\text { Understan } \\
\text { dability }\end{array}$ & Efficiency \\
\hline $\begin{array}{l}\text { Easy to } \\
\text { learn }\end{array}$ & $\begin{array}{l}\text { Learna } \\
\text { bility }\end{array}$ & $\begin{array}{l}\text { Learn } \\
\text { ability } \\
\text { (retent }\end{array}$ & $\begin{array}{l}\text { Time to } \\
\text { learn }\end{array}$ & $\begin{array}{l}\text { Easy to } \\
\text { learn }\end{array}$ & $\begin{array}{l}\text { Learnabil } \\
\text { ity } \\
\text { (ease of }\end{array}$ & & learnability & $\begin{array}{l}\text { Learnabili } \\
\text { ty }\end{array}$ & Learnability \\
\hline
\end{tabular}




\begin{tabular}{|c|c|c|c|c|c|c|c|c|c|}
\hline & & ion) & & & learning) & & & & \\
\hline $\begin{array}{l}\text { Task } \\
\text { match }\end{array}$ & $\begin{array}{l}\text { Flexibi } \\
\text { lity }\end{array}$ & & $\begin{array}{l}\text { Retentio } \\
\text { n over } \\
\text { time }\end{array}$ & $\begin{array}{l}\text { Memora } \\
\text { bility }\end{array}$ & & & $\begin{array}{l}\text { remembera } \\
\text { bility }\end{array}$ & $\begin{array}{l}\text { Operabilit } \\
\text { y }\end{array}$ & usefulness \\
\hline $\begin{array}{l}\text { Knowle } \\
\text { dge }\end{array}$ & $\begin{array}{l}\text { Attitud } \\
\mathrm{e}\end{array}$ & $\begin{array}{l}\text { Effecti } \\
\text { veness } \\
\text { (error) }\end{array}$ & $\begin{array}{l}\text { Rate of } \\
\text { errors } \\
\text { by users }\end{array}$ & Errors & $\begin{array}{l}\text { Through } \\
\text { put }\end{array}$ & $\begin{array}{l}\text { Effectivene } \\
\text { ss }\end{array}$ & $\begin{array}{l}\text { Reliability } \\
\text { in use }\end{array}$ & $\begin{array}{l}\text { Attractive } \\
\text { ness }\end{array}$ & Effectiveness \\
\hline $\begin{array}{l}\text { Motivat } \\
\text { ion }\end{array}$ & & $\begin{array}{l}\text { Attitu } \\
\text { de }\end{array}$ & $\begin{array}{l}\text { Subjecti } \\
\text { ve } \\
\text { satisfact } \\
\text { ion }\end{array}$ & $\begin{array}{l}\text { Satisfacti } \\
\text { on }\end{array}$ & Attitude & Satisfaction & $\begin{array}{l}\text { User } \\
\text { satisfaction }\end{array}$ & $\begin{array}{l}\text { Usability } \\
\text { complianc } \\
\text { e }\end{array}$ & Satisfaction \\
\hline $\begin{array}{l}\text { Discreti } \\
\text { on }\end{array}$ & & & & & & & & & Productivity \\
\hline $\begin{array}{l}\text { Frequen } \\
\text { cy }\end{array}$ & & & & & & & & & Safety \\
\hline \multirow[t]{3}{*}{$\begin{array}{l}\text { Openne } \\
\text { ss }\end{array}$} & & & & & & & & & Trustfulness \\
\hline & & & & & & & & & Accessibility \\
\hline & & & & & & & & & universality \\
\hline
\end{tabular}

Table 3 : Relations between usability criteria and characteristics for web site

\begin{tabular}{|c|c|c|c|c|c|}
\hline $\begin{array}{l}\text { Criteria } \\
\text { Characteristics }\end{array}$ & Efficiency & Effectiveness & Satisfaction & Learnability & Accessibility \\
\hline Time behavior & $\sqrt{ }$ & & & & \\
\hline Resource utilization & $\sqrt{ }$ & & & & \\
\hline attractiveness & & & $\sqrt{ }$ & & \\
\hline likeability & & & $\sqrt{ }$ & & \\
\hline flexibility & & $\sqrt{ }$ & $\sqrt{ }$ & & $\sqrt{ }$ \\
\hline Minimal action & $\sqrt{ }$ & & $\sqrt{ }$ & $\sqrt{ }$ & $\sqrt{ }$ \\
\hline Minimal memory load & $\sqrt{ }$ & & $\sqrt{ }$ & $\sqrt{ }$ & $\sqrt{ }$ \\
\hline Operability & $\sqrt{ }$ & & $\sqrt{ }$ & $\sqrt{ }$ & \\
\hline User guidance & & & $\sqrt{ }$ & $\sqrt{ }$ & $\sqrt{ }$ \\
\hline Consistency & & $\sqrt{ }$ & & $\sqrt{ }$ & $\sqrt{ }$ \\
\hline Selft-descriptiveness & & & & $\sqrt{ }$ & $\sqrt{ }$ \\
\hline Feedback & $\sqrt{ }$ & $\sqrt{ }$ & & & \\
\hline Accuracy & & $\sqrt{ }$ & & & \\
\hline Completeness & & $\sqrt{ }$ & & & \\
\hline Readability & & & & & $\sqrt{ }$ \\
\hline Controllability & & & & & $\sqrt{ }$ \\
\hline Navigability & $\sqrt{ }$ & $\sqrt{ }$ & & & $\sqrt{ }$ \\
\hline Simplicity & & & & $\sqrt{ }$ & $\sqrt{ }$ \\
\hline Familiarity & & & & $\sqrt{ }$ & \\
\hline Loading time & $\sqrt{ }$ & & & & $\sqrt{ }$ \\
\hline Effectiveness of help web site & & $\sqrt{ }$ & & & \\
\hline $\begin{array}{l}\text { Effectiveness of the user } \\
\text { documentation }\end{array}$ & & $\sqrt{ }$ & & & \\
\hline Response time & $\sqrt{ }$ & & & & $\sqrt{ }$ \\
\hline Completeness of description & & $\sqrt{ }$ & & $\sqrt{ }$ & $\sqrt{ }$ \\
\hline
\end{tabular}




\section{CONCLUSIONS}

This study has proposed a usability model for web site based on QUIM model. There are two immediate contributions of this work: comparison and analysis of existing usability model and identification of usability criteria and characteristics for web site. This model include the criteria how to measure the web site usability and not only the element. It is easier to measure the web site based on the criteria that have been given. For future research, the development of tools for usability evaluation of web site and empirical assessment of user's satisfaction

\section{REFERENCES}

[1] D. Robins and J. Holmes, "Aesthetics and credibility in web site design," Information Processing \& Management, vol. 44, no. 1, pp. 386-399, Jan. 2008.

[2] S. Elling, L. Lentz, and M. De Jong, "Website Evaluation Questionnaire: Development of a Research-Based Tool," Evaluation, pp. 293-304, 2007.

[3] J. W. Palmer, "Web site usability , design , and performance metrics," 2002.

[4] D. Whiteley, I. Hersey, K. Miller, and P. Quick, "Internet e-Commerce : buying the book and catching the plane."

[5] A. Fernandez, E. Insfran, and S. Abrahão, "Usability evaluation methods for the web: A systematic mapping study," Information and Software Technology, vol. 53, no. 8, pp. 789-817, Aug. 2011.

[6] F. B. Tan and L. L. Tung, "Exploring Website Evaluation Criteria using the Repertory Grid Technique: A Web Designers "Perspective," Technology, pp. 65-69, 2003.

[7] C. C. Whitehead, "Evaluating web page and web site usability," Proceedings of the 44th annual southeast regional conference on - ACM-SE 44, p. 788, 2006.

[8] F. Montero, P. González, M. Lozano, J. Vanderdonckt, G. D. I. Louise, and E. Uclm, "Quality Models for Automated Evaluation of Web Sites Usability and Accessibility," 2005.

[9] K. E. Schmidt, M. Bauerly, Y. Liu, and S. Sridharan, "WEB PAGE AESTHETICS AND PERFORMANCE: A SURVEY AND AN EXPERIMENTAL STUDY," in Proceedings of the 8th Annual International Conference on Industrial Engineering, 2003, pp. 478-484.

[10] A. Seffah, M. Donyaee, R. B. Kline, and H. K. Padda, "Usability measurement and metrics: A consolidated model," Software Quality Journal, vol. 14, no. 2, pp. 159-178, Jun. 2006.

[11] S. K. Dubey and A. Rana, "Analytical Comparison of Usability Measurement Methods," vol. 39, no. 15, pp. 11-18, 2012.

[12] B. Behkamal, M. Kahani, and M. K. Akbari, "Customizing ISO 9126 quality model for evaluation of B2B applications," Information and Software Technology, vol. 51, no. 3, pp. 599-609, Mar. 2009.

[13] C. J. Granizo, P. L. Yanez, D. P. Ramirez, and P. C. Machado, "Usability in E-government Sites," 2011 Eighth International Conference on Information Technology: New Generations, pp. 453-458, Apr. 2011.

[14] F. Computer, M. Sciences, U. Teknologi, M. Uitm, and S. Alam, "Assessing the Accessibility and Usability of Malaysia Higher Education Website," vol. 3, no. 2008, pp. 203-208, 2010.

[15] R. Ramli, "Design and Development of e-RUE as a Web-based Evaluation Tool," Symposium A Quarterly Journal In Modern Foreign Literatures, pp. 1-6, 2010.

[16] Y. Lee and K. a. Kozar, "Understanding of website usability: Specifying and measuring constructs and their relationships," Decision Support Systems, vol. 52, no. 2, pp. 450-463, Jan. 2012.

[17] L. Leventhal and J. Barnes, Usability Engineering Process, Products, and Examples. Pearson Prentice Hall, 2008.

[18] M. De Marsico and S. Levialdi, "Evaluating web sites: exploiting user's expectations," International Journal of Human-Computer Studies, vol. 60, no. 3, pp. 381416, Mar. 2004.

[19] Z. Balfagih and M. Mahmud, "In Search of a Model for Evaluating the Quality of E-Commerce Web sites," Quality, no. December 2007, pp. 2-7, 2008.

[20] S. K. Dubey and A. Rana, "Analytical Roadmap to Usability Definitions and Decompositions," vol. 2, no. 9, pp. 4723-4729, 2010.

[21] N. Bevan, "Quality and usability: A new framework," no. figure 1, pp. 1-8, 1997.

[22] A. Abran, A. Khelifi, W. Suryn, and A. Seffah, "Usability Meanings and Interpretations in ISO Standards," Software Quality Journal, vol. 11, no. 4, pp. 325-338, 2003.

[23] J. Wang and S. Senecal, "MEASURING PERCEIVED WEBSITE USABILITY," Journal of Internet Commerce, vol. 6, no. 4, pp. 97-112, 2008.

[24] D. Karahoca, A. Karahoca, A. Karaoglu, B. Gulluoglu, and E. Arifoglu, "Evaluation of web based learning on student achievement in primary school computer courses," Procedia - Social and Behavioral Sciences, vol. 2, no. 2, pp. 5813-5819, Jan. 2010.

[25] J. Jeng, "Usability Assessment of Academic Digital Libraries: Effectiveness , Efficiency, Satisfaction , and Learnability," vol. 55, pp. 96-121, 2005.

[26] N. S. Bazar, "Web Usability or Accessibility: Comparisons between people with and without intellectual disabilities in viewing complex naturalistic scenes using eye-tracking technology," George Mason University, 2009. 
[27] K. A. Jadhav, "Understanding Usability and User Experience of a Technology Enhanced Role-Playing System," University of Calgary, 2010.

[28] A. Madan and S. K. Dubey, "USABILITY EVALUATION METHODS: A LITERATURE REVIEW," vol. 4, no. 02, pp. 590-599, 2012.

[29] P. Booth, An Introduction To Human-Computer Interaction. Taylor \& Francis, Inc, 1989.

[30] J. Rubin, Handbook of Usability Testing: How to Plan, Design, and Conduct Effective Tests. Wiley Technical Communications Library, 1994.

[31] J. Rubin and D. Chisnell, Handbook of Usability Testing: Howto Plan, Design, and Conduct Effective Tests, 2nd Edition. 2008, p. 384.

[32] J. Nielsen, "Usability 101: Introduction to Usability," 2003. [Online]. Available: http://www.useit.com/alertbox/20030825.html. [Accessed: 06-Jun-2012].

[33] S. U. Services, H. Court, and L. Wcv, "International Standards for HCI," no. May, pp. 1-15, 2006.

[34] P.-Y. Yen, "Health information technology usability evaluation: methods , models , and measures," Columbia University, 2010.

[35] A. Hussain and E. Ferneley, "Usability Metric for Mobile Application: A Goal Question Metric ( GQM ) Approach," pp. 567-570, 2008.

[36] R. E. Al-qutaish, "Quality Models in Software Engineering Literature: An Analytical and Comparative Study,” vol. 6, no. 3, pp. 166-175, 2010.

[37] A. Khalili, "User Interfaces for Semantic Content Authoring: A Systematic Literature Review," no. May, 2012.

[38] I.-F. Liu, M. C. Chen, Y. S. Sun, D. Wible, and C.-H. Kuo, "Extending the TAM model to explore the factors that affect Intention to Use an Online Learning Community," Computers \& Education, vol. 54, no. 2, pp. 600-610, Feb. 2010.

\section{BIOGRAPHIES:}

Nur Sukinah Aziz (Corresponding author) is a lecturer at the Faculty of Computer, Media and Technology Management, TATI University College (TATIUC), Teluk Kalong, 24000 Kemaman, Terengganu, Malaysia. Her research interest includes web based, multimedia, HCI and software engineering education system.

Dr. Adzhar Kamaludin is a senior lecturer at the Faculty of Computer Systems \& Software Engineering Universiti Malaysia Pahang, Kuantan, Pahang, Malaysia.His research interest includes software engineering, information retrieval

Dr. Norrozila Sulaiman is a senior lecturer at the Faculty of Computer Systems \& Software Engineering Universiti Malaysia Pahang, Kuantan, Pahang, Malaysia.Her research interest includes networking, software engineering, information retrieval 